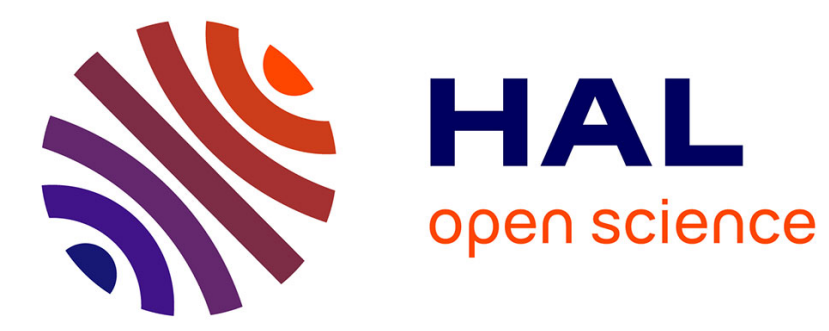

\title{
Book Review: Reading Sex and the City Rachel Moseley
}

\section{To cite this version:}

Rachel Moseley. Book Review: Reading Sex and the City. European Journal of Cultural Studies, 2005, 8 (1), pp.125-127. 10.1177/1367549405049498 . hal-00571468

\section{HAL Id: hal-00571468 https://hal.science/hal-00571468}

Submitted on 1 Mar 2011

HAL is a multi-disciplinary open access archive for the deposit and dissemination of scientific research documents, whether they are published or not. The documents may come from teaching and research institutions in France or abroad, or from public or private research centers.
L'archive ouverte pluridisciplinaire HAL, est destinée au dépôt et à la diffusion de documents scientifiques de niveau recherche, publiés ou non, émanant des établissements d'enseignement et de recherche français ou étrangers, des laboratoires publics ou privés. 


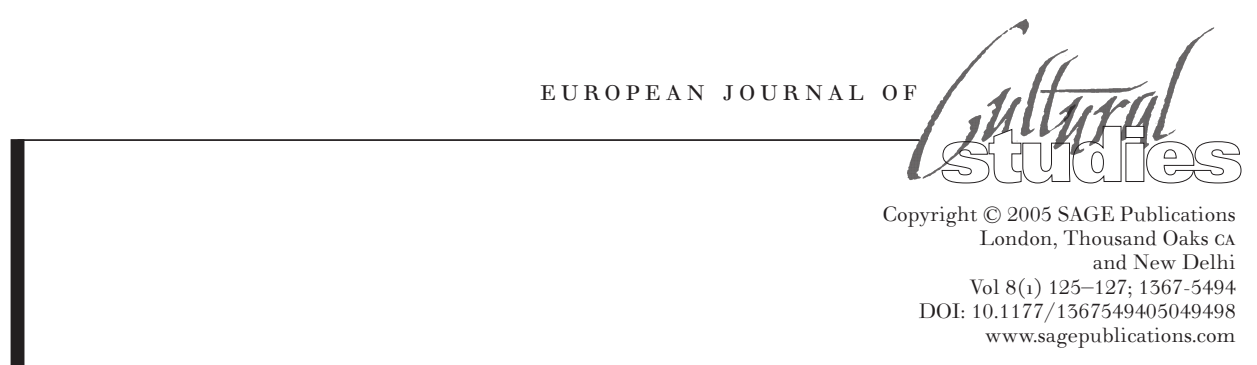

\section{Book review}

Kim Akass and Janet McCabe (eds), Reading Sex and the City. London and New York: I.B. Tauris, 2004. 273 pp. ISBN 1-85043-423-9 (pbk)£12.95

Reading Sex and the City aims to offer a scholarly engagement not just with what has become an internationally acclaimed and extremely popular television programme, but also with its existence in the wider culture, in spaces such as the fashion press, female friendship networks and New York City bus tours. The book brings together scholars from a range of international academic contexts, and the resulting collection of essays is an interdisciplinary work which offers a range of perspectives and methodological approaches - sometimes productively conflicting - on the cultural phenomenon that is Sex and the City. As the editors suggest in their introduction, 'One of the central aims of this anthology is to locate new ways of speaking and thinking about a popular cultural text that continues to be a site of contestation' (p. 7), and the presentation of the essays in sections addressing questions of sexuality, identities, fashion, narrative and fandom is an organizational strategy which allows commonalities and tensions between the pieces to emerge. The strength of the collection lies in its engagement with debates key to the study of contemporary popular culture - from sexuality to flânerie - and in particular to the study of women's television through the consideration of what seems to have become a 'canonical' text in this field. A number of the essays engage with current debates around post- and third-wave feminisms and in the process raise questions - both explicitly and implicitly - about the possible depoliticization of feminist cultural analysis.

In the first section 'Sex, Sexuality and Relationships', Joanna di Mattia argues that the show is engaged in a deconstruction of the classic romantic quest for 'Mr Right', and in revealing the impossibility of defining that ideal 'after feminism'. In a useful juxtaposition, the essay which follows, by David Greven, illustrates the extent to which Sex and the City both displays and deconstructs white masculinity. His suggestion that the show

has its men and eats them, too - it both gets to indulge in intense fantasies of the acquisition and consumption of deliriously desirable, Olympian models of white male physical perfection and aggressively kicks these gods off their cloud nine perches (p. 38) 
suggests the way in which the show articulates the contradictions contained in the post-feminist position of 'having it all' in relation to masculinity as much as femininity. His final position is less positive in its assessment of the show, seeing it as a misogynist and homophobic text which ultimately fails to make a convincing critique of male power - an argument which no doubt will be the starting point for further work in this area.

Mandy Merck's essay in this collection addresses the exclusions of the post-feminist agenda in relation to sexuality and specifically lesbian identity, while Astrid Henry's essay, which follows it, offers an interesting counterpoint with a discussion of the show as a 'third-wave' text addressing questions of sexual identity in a generationally specific way which problematizes heterosexuality. The remaining essays in this section on identities are concerned with questions of citizenship and consumption, an area of cultural studies in which there remains important work to be done. Ashley Nelson and Susan Zeiger here provide new starting points for that debate to be reinvigorated. Nelson offers a productive discussion of the show in relation to Theodore Dreiser's Sister Carrie, thus placing the text and its heroine in a continuum which produces an illuminating account of contextually specific cultural shifts. Zeiger opens up the show's suggestion of 'the sexual citizen' as a significant category for further discussion.

Section Three, 'Fashion and Cultural Identities', examines an aspect of Sex and the City which has been at the heart of its popularity and success, but which also has been the foundation of its 'extra-textual' life in the form of other cultural forms and practices (journalism, shopping, identity production), locating this show as ripe for cultural analysis not only through textual analysis, but also in relation to fashion theory and through audience research methods. Accordingly, Bruzzi and Church Gibson offer an enlightening discussion of the role played by fashion in relation to costume, character and spectacle in the programme, and Anna König looks at the life of the programme in British fashion journalism as a form of cultural production. Sarah Niblock's essay on the semiotics of Manolo Blahnik's shoe designs, while a short piece, is a genuinely illuminating piece of cultural and textual analysis.

In the section on narrative, genre and intertextuality, Tom Grochowski examines the series in relation to the 'nervous romances' of Woody Allen, and finds it somewhat wanting, arguing that the television series format has allowed an expansion and reworking of the Allen 'formula' but has also limited its potential for social critique, a position with which I suspect will be productively engaged by scholars in television and cultural studies. Jonathan Bignell links the show to other 'women's genres' such as talk shows and magazines in relation to representational politics, and addresses the role played by self-reflexivity in the programme. Bignell argues, for example, that the show's humorous and self-aware address to the question 126 of commodity fetishism remains at the level of character self-questioning 
rather than cultural critique. It is in this area, of the relationship between identity, politics and consumption, that the collection is most suggestive, and offers points from which the debate could be furthered productively. The editors' own essay focuses on the question of narrative agency, usefully bringing an arrangement of theoretical perspectives, from Althusser to Modleski, to bear on a text which in this piece proves itself to be enormously fruitful as an object of cultural analysis. In the final of the main essays in the collection, Deborah Jermyn shows, through a smallscale qualitative audience research study, just how rich a text Sex and the City will prove to be for further investigation of this kind.

The short pieces that conclude the collection are written by Akass and McCabe, Lucia Rahilly, Ashley Nelson and Mark W. Bundy, all of whom took the 'Sex and the City' bus tour around New York City and reflect on the experience in their contributions. Initially I was unsure how useful the inclusion of these pieces would be in the collection, but in fact these brief essays proved to be the highlight of the book, with the writers offering illuminating, self-reflexive and divergent accounts of the same experience which illuminate the agendas and impact of this 'post-feminist' show. In her piece, Ashley Nelson points to the dichotomy between a scholarly approach to the show which finds it difficult to admit its own investment in the show, and the bawdy fandom that she witnessed on the tour. This question, it seems to me, is at the heart of the difficulty that the British press have found in taking this publication seriously. The book has received a number of reviews which have criticized the collection itself for taking the show seriously, in an all-too-familiar response to scholarly work which addresses the popular, and especially popular television. In their essay, Akass and McCabe draw upon Foucault to discuss the dilemma of talking openly about sex and the disciplinary techniques which then come into play. One might argue that, through the media response to this book, a similar and not unlinked disciplinary mechanism has been demonstrated. The serious attention to a popular media text that this collection represents might constitute an equally serious threat to the institutions which produce it.

\section{Rachel Moseley University of Warwick}

